\title{
Code-Switching and Identity: A Sociolinguistic Study of Hanif's Novel Our Lady of Alice Bhatti
}

\author{
Sumaira Akhtar ${ }^{1}$, Fatima Zafar Baig ${ }^{1}$, Muhammad Zammad Aslam², Talia Khan ${ }^{2}$, Sunbal Tayyaba ${ }^{2} \&$ \\ Zafar Iqbal $^{3}$ \\ ${ }^{1}$ National College of Business Administration \& Economics, Multan, Pakistan \\ ${ }^{2}$ National University of Modern Languages, Islamabad, Pakistan \\ ${ }^{3}$ MPhil Scholar, Minhaj University Lahore, Pakistan \\ Correspondence: Muhammad Zammad Aslam, National University of Modern Languages, Islamabad, Pakistan. \\ E-mail: zammad.aslam@gmail.com
}

\author{
Received: October 1, 2019 Accepted: December 20, 2019 Online Published: January 2, 2020 \\ doi:10.5539/ijel.v10n1p364 URL: https://doi.org/10.5539/ijel.v10n1p364
}

\begin{abstract}
The present research explores the features of code-switching in Hanif's (2011) English fictional novel Our Lady of Alice Bhatti. The research explores code-switching by applying the Whorfian Hypothesis (Linguistic Relativity and Determinism) through textual analysis of Hanif's novel (2011). One of the distinguishing features of the novel is the use of two distinct languages (English and Urdu) which majorly cause the implementation of various features of code-switching and code-mixing. The researchers have employed the qualitative research approach during data analysis. The study examines how language influences ideas and identity with the use of code-switching. A comprehensive study or analysis of the relevant literature has also presented in a comprehensive way leading towards a theoretical framework of preferred Whorfian Hypothesis (Sapir-Whorf Hypothesis) in the field of sociolinguistics. The results and findings of the also proves that the writer of the novel consciously/unconsciously utilizes the technique of code-switching of code-mixing to highlight/promote the native/local identity (ies) and cultural values through the code-mixed language. The study would be helpful for the reader to develop an appropriate understanding of code-switching in language varieties.
\end{abstract}

Keywords: code-switching, code-mixing, identity, ideas and ideologies, culture

\section{Introduction}

In this section of the research, the researchers have provided an overview of the topic of the present research. The researchers have also highlighted definitions of key terms and also explained the use of code-switching in the Pakistani context comprehensively, so, it is enough to comprehend the scope and significance of code-switching which indicates the ideas and ideologies of this patriarchal society. In the recent decade, psychologists, anthropologists as well as sociolinguists have also conducted various researches in the sub-field (linguistics) of code-switching. As an emerging trend of sociolinguistics, the research field of code-switching has become vast. Therefore, code-switching determines the relationship between language use and the individuals who use it as a communicative approach to fulfill the requirements of communication within a social and cultural context (Myers-Scotton, 1993). Language constructs or destructs identities and ideologies of any society, for instance, Halliday (1978) argues that language is a social semiotic and people use it on a regular basis to communicate with each other. So, language reflects, records and transmits social differences (Spolsky, 1998). Therefore, a language defines the behavior of people in a given society. For instance, "Language Practices are socially as well as politically restricted" (Heller, 2007, p. 1). Moreover, a language could be considered as transplanted if it is used by considerable numbers of speakers in cultural, social geographical contexts dissimilar from the context in which it was originally used as a transplanted language (Kachru, 1989).

Sociolinguistics is the branch of linguistics and sociology that studies the individual and social variation of language (Spolsky, 2010) which demonstrates the relationship between language use and the social basis for such use (Hudson, 1980). Moreover, sociolinguistics also determines how language and culture are interlinked and how language is used in different social contexts (Bell, 1976). Furthermore, sociolinguistics is also the study of stylistic and social variation of language (Wardhaugh, 1998) as well as the study of language in relation to its socio-cultural 
context (van Dijk, 2009). Hence, "Sociolinguistics involves dialectology, discourse analysis, ethnography, secular linguistics, the social psychology of language and the sociology of language" (Trudgill, 2003, p. 123).

Our Lady of Alice Bhatti (2011) is the second famous novel of Hanif which has grounded on the victimization of women by male-dominated society. For instance, in the story of the novel, the protagonist Alice (a female character) is a working-class Christian woman who lives and works in a metropolitan city (Karachi) of Pakistan. Alice wants to live and survive in a patriarchal society as a respectable woman, but unfortunately, she dies in a brutal way suffering the brutality of the patriarchal society (see Hanif, 2011 for more details). So, Hanif (2011) has clearly exposed the ideas and ideologies related to women who live and survive in a patriarchal society involving the local expressions through the code-switched language. The ideas and ideologies have clearly represented how cultural traditions and class differences ruin the lives of women in a patriarchal society. Moreover, Hanif is also the author of the highly acclaimed novel A Case of Exploding Mangoes (2008) which was shortlisted for the Guardian First Book Award and the winner of the Commonwealth First Book Award. Furthermore, Hanif, a novelist, play-writer, journalist, and author lives in Pakistan. He works in News Line and The Washington Post (Random House India).

\subsection{Purpose of the Research}

Language represents ideas and ideologies of any society. In Pakistani culture, the English language retains the liberal values of western society as an official language. However, English is considered as a language of empowerment in the contemporary world as well as in Pakistan. So, the researchers have tried to find out the constructions of local identity (ies) with the help of code-switching and code-mixing techniques utilized in the novel. Moreover, the present research also delimits itself only with the phenomenon of code-switching in Hanif's novel (2011). The present study has been conducted in the field of linguistics (specifically in sociolinguistics), so, the written text of the novel has been preferred and studied rather than film or television. Moreover, the objectives of the present research are to represent power relations in patriarchal society through code-mixing in Hanif's novel (2011); to interpret the status of women constructed through ideas and ideologies in a metropolitan city (Karachi) of Pakistan.

Furthermore, through the findings of the research, the researchers have tried to answer the following questions:

1) How social identities and power relations have exposed through code-switched language by the writer?

2) How has code-switch language represented ideas as well as ideologies about women in Hanif's novel Our Lady of Alice Bhatti (2011)?

3) How has code-switched language constructed social and cultural identities in a patriarchal society?

\subsection{Significance of the Study}

The researchers have explored the identities and ideologies through the present research which have seemed embedded in code-switched language structures of Hanif's novel (2011) named Our Lady of Alice Bhatti. Moreover, the study specifically focuses on the local cultures, customs, norms, values and social practices that have presented through the mixed language in the novel. Furthermore, the researchers also have examined how the non-native writers of the English language often try to construct or deconstruct their local ideas and ideologies of their society into Standard English specifically in the postcolonial era. Although, the present research is a pilot study of the novel, yet, it would be supportive for the future researchers to get new dimensions for their own studies regarding code-mixing and sociolinguistic concerns specifically in the non-native writings of the English language.

\section{Literature Review}

In the literature review, the study consists of several prior researchers regarding the core issue of the research. The theoretical framework of the study provides support to the research in a comprehensive manner.

Anwar (2007) concludes his research with the variation of Urdu phrases and clauses in Pakistani English as a non-native speaker of the English language. Anwar extracts the data from Pakistani English Newspapers and journals. He has found the use of Urdu clauses and phrases in Pakistani English. Accordingly, the manifestations of several Urdu phrases and clauses impose grammatical effects on the construction of the English language. Language is a form of social practice, in the center of which power and ideology mutually influence and interact with one another (Fairclough, 2001). Furthermore, Gulzar (2009) explores the practicalities of code-switching in the education system of Pakistan. Hence, the present study is distinguished itself from the above-mentioned studies as it explores the code-switching and code-mixing specifically in fictional writing. 


\subsection{Theoretical Framework}

Theory plays a vital role in the research work. Because of theory (ies), researchers try to identify the facts about their concerned studies. In this study, the researchers employ the Whorfian Hypothesis to identify code-switch language in Hanif's novel (2011).

\subsubsection{Whorfian Hypothesis/Sapir-Whorf Hypothesis}

Sapir (1884-1939), is an American anthropologist, linguist and a great teacher of Whorf. Both Sapir and Whorf purposed the relationship between language, thought, and culture. The Sapir-Whorf Hypothesis revolves around the idea that language possesses the power to control. Language supports your ideas and structures your thoughts. Language as a tool provides the framework which describes the said and unsaid meaning of words. Sapir and Whorf define that our culture determines our language and thought about the world and our experiences in it. People who speak different languages, think differently (Kevin, J. Holmes).

Sapir defines the close relationship between language and culture. Any culture exists due to language which is the medium of expression for their society (Sapir, 1929, p. 207 as cited in Joseph, 1996). Language concludes how speakers perceive, organize as well as summarize the world around them. Subsequently, the world is not simply the way it is, but what we make of it through language (Romaine, 1999).

\subsubsection{Code-Switching}

Code-switching is considered as a practice of language(s). If the speaker of one language (L1) changes their language abruptly into the second language (L2) during communication that would be the code-switching. The use of two languages at the same time is called as bilingualism. The phenomenon of bilingualism is termed as code-switching. "Switchback and forwards between languages, even during the same utterance" (Mesthrie et al., 2000, p. 146). It depends on speaker's choice that language speaker uses in possible expression (Romaine, 1994, p. 9 as cited in Mesthrie et al., 2000, p. 10) cites as (Gumperz, 1982a, p. 59) that codeswitching is the combination of (within the same speech exchange of passages of speech fit into) two or more than two different grammatical systems or sub-systems. The core purpose of code-switching is to arouse or change interpersonal relations with their rights and obligations (Gal, 1989, p. 347). Code-switching denotes hidden prestige which is revealed through attitudes (Auer, 2002). Code-switching is about to show power over the less powerful (Al-Khatib, 2003).

\subsubsection{Code-Mixing}

"The way in which language figures in everyday interaction and cognition" (Ochs, Schegloff, \& Thompson, 1996, p. 2). Code mixing is termed as intra-sentential switching. In code mixed language, chunks/ parts of one language (L1) are embedded in the other language (L2) when a speaker utters the second language (L2). The chunks of other language(s) might be frequently words, phrases, and clauses. Role identification, register identification, and interpretation are the three basic elements of code-mixed language (Kachru, 1978, p. 36). Any sentence consists of lexical items and grammatical features in any language (Muysken, 2000, p. 1). Code-mixing comprises mixing of words from one language to another language and practice at the sentence level repetitively.

\subsubsection{Linguistic Identity}

Language is both an individual possession and a social possession (Wardhaugh, 1998, p. 116). Language as a powerful tool creates the strong linkage among people through social, cultural, economic as well as religious identity (ies). The book Language and politics in Pakistan (1996) of Tariq Rehman represents the importance of language. According to Rehman, when different communities compete for power and resources then language becomes a symbol of identity.

\section{Research Methodology}

The researchers employ a qualitative approach in the present study. The chapter of research methodology involves the whole procedure of design, data sources as well as data analysis in a clear and lucid manner. The study follows the qualitative approach. The qualitative approach revolves around vast knowledge which comprises of issue-oriented, change-oriented, political as well as constructivist (Creswell, 2013, p. 18). Lincoln (2000) identified the qualitative approach as an effective way of getting information about cultures, customs, and norms about any society. That's why the researchers have adapted the qualitative approach to analyze the text of code-switched language in Hanif's novel (2011). The study would be abundantly helpful for the readers.

The researchers present a few sources before actual research work. The study is based on the text of the selected Hanif's Novel (2011). Along with the original text, the researchers acquire the literary works (feministic perspective, religious aspect, suppression of women) of the novel to know about the literary styles for writing the research paper. The researchers analyze the text of the novel to explore the Urdu code-switched linguistic patterns 
in Pakistani English novel of Hanif (2011). A phenomenon of code-switching could be observed through selected words and phrases of Urdu language in English fiction novel. An analysis of code-mixing is noticed from two perspectives, one is a linguistic perspective and the second is a social perspective. The researchers divide the data into two categories. Category one specifies the morphological analysis of the selected text at the level of lexical items. Category two describes the sociolinguistic analysis of Urdu code-mixed language.

\section{Data Analysis}

\subsection{Category 1: Morphological Analysis}

In the section of textual analysis, employing the purposive sampling technique, the researchers have separated and selected the sentences containing the English/Urdu code-mixing from Hanif's novel (2011). Hanif has mixed Urdu words in Pakistani English literature, particularly in the novel to depict the language and culture of Pakistan. For instance, the use of multi-words (taken from two languages) indicates the emerging trends of code-switching in languages of the contemporary world. Several words such as Sahib (Sir), Dard (Pain) aur (or) Dawa (medicine), Choohra (untouchable), Hazir (Present) ho (be), Kakoo, Kala (Black), oye (to call someone), Biryani (a dish of rice and chicken) and Bhai (brother) indicate the cultures, customs, values, and identities of Pakistani society. It shows that power (English language) replaces the identity of a national language (Urdu) of Pakistan. Hence, the English people or the native writers of the English language had wanted to rule over the eastern culture through the strong impact of language, yet, the writer of this novel has consciously/unconsciously tried to break this phenomenon of supremacy of the English language.

According to the data, the researchers have found and defined the words of Urdu language in Pakistani English fiction that represent Pakistani language(s) and culture(s). For instance, the words like Bhai (Brother), Bhabhi (sister-in-law), Memsahib (Madam), Sahib (Sir) have identified that represent Pakistani culture(s) and norm(s) in the Pakistani national language, Urdu. These Urdu words have utilized to address different relationships, social statuses or distinct gender. Such as, Bhai has utilized instead of the English word Brother. Moreover, Bhabhi has utilized instead of sister-in-law (especially for the wife of younger/elder brother). Memsahib (Urdu word) has utilized to address a woman who keeps a respectable or high social status, whereas, Sahib has utilized for a man who keeps a remarkable status or position in society. Although in western society, the concept of Memsahib or Sahib has not found linguistically, yet, they often add Mr. or Miss. before the name any individual respectively to give respect to any man or woman while addressing. Ironically, in the case of the present novel, Hanif (2011) has not used/utilized the word of Madam for Alice (protagonist) as the society does not consider her a respectable lady of the society. On the other hand, he has utilized the Urdu Word Sahib for his character Teddy Butt consciously or purposefully. So, the Hanif has tried to expose the discriminatory attitude of the society that only favors and gives respect only to a man.

Moreover, the words like Daal (pulse), Aloo (potato), Gosht (meat), Ajwain (carom seed), Kebab (roast) Basmati (a kind of rice) and Biryani (a spiced dish of rice and chicken) have also found that have utilized to represent the culinary and traditional food names of Pakistan. Furthermore, words like Dupatta, Shalwar, Dhoti have also utilized to represent the local Pakistani dresses. For instance, these simple named of dresses in the Urdu language specifically have utilized to represent the simplicity of the cultural values through the typical dressing of common people of Pakistan. For instance, Dupatta has utilized to depict the simplicity and the icon of respectability of the common woman of the society, yet, if a woman does not wear Duppata, the society does not consider her a respectable woman. Moreover, the word Shalwar has utilized instead of trousers or pants and it could be worn by both respectable men and women. Furthermore, Dhoti has utilized for the simplest men of the society who live specifically in rural areas of Pakistan.

The religious words like Musalman (Muslim), Yasoo (Jesus), Masih (Christian), Kafir (non-believers), Halaal have utilized to denote the religious identity (ies) of the metropolitan city (Karachi) in Pakistan. For instance, the purpose of the utilization of these words of the Urdu language has appeared to distinguish the importance of religion in the society as the word Musalman (Muslim) symbolizes the believer of Allah and Islam while Kafir (non-believers) is an absolute opposite of Musalman (Muslim) - Kafir is non-believer of Allah/Islam according to the cultural and religious concepts of the society of Pakistan. Henceforth, Masih and Kafir consciously utilized/used to represent distinctive purposes/concepts as most of the people of the society do not understand the vivid distinctiveness of both words. For instance, the word Masih has only utilized to represent the Christian community, yet, Kafir for only non-believers God. Last but not the least, the word Halaal has also utilized to distinct the religious values of the individuals living within the same society keeping unified cultural and social values, for instance, the women of the society (Muslim, Christian or others) wear Duppata as a cultural identity. Hence, the Muslim community of the society restricts itself to eat Halaal food, yet, the other religions do not 
restrict themselves with this concept. For instance, pork is prohibited in Islam, yet not in other religions of the society.

\subsection{Category 2: Sociolinguistic Analysis}

Sociolinguistics (Language + society) identifies the ideological, political, cultural as well as social practices which exist in contemporary society (ies). Society refers to the group of people where they live together and co-ordinates with each other. The maximum use of language promotes the phenomenon of globalization.

Hanif portrays the horrific glimpse of society particularly for women in the novel Our Lady of Alice Bhatti (2011). Consequently, Alice identifies herself as the sort of woman who fascinates men. As a result, she tries to maintain an avoiding-eye contact and conversation with those people who look at her as an ordinary and abhorrent object. Furthermore, she avoids eating in an open/public place in front of the public because she accepts the social taboos related to women, for instance, if a woman puts something into her mouth publically, actually, is an open invitation for someone to quench his horrific thirst or desire. If a woman shows her deprivation or asks for something, she becomes the victim of violence in the form of a brutal criticism by the society.

In this novel, sexual objectification has referred to an object to exciting the sexual desires. For instance, Hanif (2011) narrates in his novel "Alice Bhatti Hazir ho" (p. 48). After that, Alice fights persistently against the social stigmas, embarrassments, abuses, indignities, and misconducts of patriarchal society. Moreover, the protagonist (Alice) tries to seek a secure roof over her head with the support of her husband but she finds herself helpless and isolate. Teddy (Husband of Alice) suspects just because of her status as she is a nurse at the hospital. For instance, a nurse as a professional person is considered a disgustful individual, particularly in Asian culture. Women are only supposed as sexual objects as well as decoration pieces (inanimate) of beatification for homes. So, the protagonist (Alice) and other female characters such as Hina Alvi (nurse), Margaret (mother of Alice) expose the dark aspects of society towards women. Furthermore, Hanif (2011) exposes the bitter fact that lower-class women lead a very susceptible life with oppression and exploitation: "her twenty-seven-year-old body is a compact little war zone where competing warriors have trampled and left their marks" (Hanif, 2011, p. 174).

Moreover, Hanif (2011) depicts the pity situation of Pakistani society where religious minorities protect themselves through the transformation of their names based on religion. A society's culture consists of whatever it is one must know or believe in order to operate in a manner acceptable to its members and to do so in any role that they accept for anyone of themselves. Hanif (2011) has consciously discriminated the protagonist female character from other characters in the text in this manner: "Alice does not like to be like other women. She tries to maintain a non-descript exterior; she learns the sideways glance instead of looking at people directly. She speaks in practiced, precise sentences; so that she is not misunderstood. She avoids eye contact and she never eat in public" (Hanif, 2011, p. 145).

\subsection{Language, Power and Identity}

Language as a social practice enables people to negotiation, argument, and discussion in any society. Languages and the use of language manifest 'who we are' and we define reality partly through our language and linguistic behavior (Wodak, 2003). Identity is the prototype of ideology. Language grows out of life, out of its needs and experiences. Language is not merely a tool of communication while it is directly associated with ideology (ies). Man is always exposed as dominant, powerful, authoritative while woman is exposed as submissive, subordinate, powerless, fragile, obedient as well as innocence. It is commonly said that women have power in their mouths and men have the power in their fists. People are considered as part of the elite group who possess power. The use of the English language is considered as the part of elite social status. Because of this, the elite class refers to their children in English medium schools to achieve a higher social, cultural as well as political status. According to Rahman (1990), the English language is regarded as a symbol of power as well as the trait of modernization. In the power structure(s) of Pakistani society, the protagonist (Alice) belongs to the religious group of Christianity. Being a minority, Alice belongs to working-class status which deteriorates her position of nurse just because of marginalization, demoralization in male-dominated (patriarchal) society. The Christian institute or school of nursing was threatened by the presence of Muslims what she calls Musla (Muslim) girls and the same girls did attack her when Alice called the Kafir den (Hanif, 2011, p. 172). Then the voices of slogans: "Who belongs to Pakistan, Musalman, Musalman" (Hanif, 2011, p. 172).

The use of English language in Hanif's novel (2011) demonstrates the tendency of globalization. People need to learn Urdu and English to empower themselves and get a remarkable status in Pakistan. The use of code-switching in the present study reveals the power ideology and social identity. 


\section{Conclusion}

The present study has exposed different ideas and ideologies through code-switching or ideological positioning from different perspective of religious (especially Muslims and Christians) lifestyles of metropolitan city (Karachi) in Pakistan. Hanif's novel (2011) has depicted a highly effective story which highlights the representation of social and cultural practices, norms, customs, values, as well as power relations in a comprehensive manner. Various social identities have also reflected through the use of Urdu words in English fictional novel of Pakistan. The researchers have predicted that the novel revolves around disappointed Christian communities of Pakistani society where they lose their identity when Muslims call them Choorha (submissive individuals). Partially, women also face discriminatory attitude of the Muslim majority. Through the narrative, Hanif has also mocked the social as well as religious detachments in today's Pakistani society.

\subsection{Contribution of the Research}

The researchers have predicted the sociolinguistic phenomenon of code-switching in the Pakistani fictional novel by Hanif (2011). The recent research contributes to prominent grounds of sociolinguistics. Moreover, the researchers have examined the specific linguistic concerns which are closely related to code-switching. It also helps to enlighten the influence of modernism as well as globalization in language construction. The present study also develops an understanding of code-switching in a lucid and clear manner on the contrary of ideological, identical and cultural aspects of code-switching.

\subsection{Suggestions for Further Researches}

At the present stage, the present research highlights the facts related to the ideological representation of language through code-switching in Hanif's (2011) novel Our Lady of Alice Bhatti. The current research could also be employed, adding various other contemporary frameworks of code-switching, on other English fictional works. For instance, the marginalization of women in patriarchal society, representation of working-class women as well as ill-treatment towards minorities in Hanif's novel (2011) could also be explored in future researches.

\section{References}

Ahmad, S. (2011). Concord with collective noun in Pakistani English. M.Phil. Thesis. Faisalabad: Government College University.

Ahmed, R., Ahemed, R., \& Seemab, G. (2015) Concepts of Code Switching and Code Mixing as Facilitators in Urdu EFL class. Journal of Policy Research, 1(2), 62-66.

Al-Khatib, H. (2003). Language Alternation among Arabic and English Youth Bilinguals: Reflecting or Constructing Social Realities? International Journal of Bilingual Education and Bilingualism, 6, 409-422. https://doi.org/10.1080/13670050308667794

Anderson, B. (1983). Imagined Communities. London: Verso.

Anwar, B. (2009). Urdu-English code-switching: The use of Urdu phrases and clauses in Pakistani English (A non-native variety). International Journal of Language Studies, 17, 1-14.

Auer, P. (2002). Code-switching in conversation: Language, interaction and identity. New York: Routledge.

Bell, D. (1976). The Cultural Contradictions of Capitalism. New York: Basic Books. In J. E. Morris (Ed.), Assessing Western Australian Year 11 students' engagement with responding in Visual Arts. Retrieved November 20, 2019, from https://ro.ecu.edu.au/theses/1627

Creswell. (2013). Research Design (2nd ed.). London: Sage Publication.

Crystal, D. (2003). English as a Global Language (2nd ed.). Cambridge: Cambridge University Press.

Fairclough, N. (2001). Language and Power (2nd ed.). New York: Longman.

Gal, S. (1989). Language and political economy. In R. Mesthrie, J. Swann, A. Deumert \& W. L. Leap (Eds.), Introducing Sociolinguistics (ARA 18: 345-67). Edinburgh: Edinburgh University Press.

Gulzar, M. A. (2009). Classroom Discourse in Bilingual Context: Effects of Codeswitching on Language Learning in Pakistani TEFL Classroom. Ph.D. Dissertation. National University of Modern Languages, Islamabad, Pakistan. Retrieved October 10, 2019, from http://prr.hec.gov.pk/jspui/bitstream/123456789/1865/1/1385S.pdf

Gumperz, J., \& Levinson, S. (1996). Introduction to part I. In J. J. Gumperz \& S. C. Levinson (Eds.), Rethinking Linguistic Relativity (pp. 21-36). Cambridge, UK: Cambridge University Press.

Gumperz, J. J. (ed.) (1982a). Language and Social Identity. Cambridge: Cambridge University Press. 
Hanif, M. (2011). Our Lady of Alice Bhatti. Vintage Digital.

Heller, M. (2007). Bilingualism as ideology and practice. United States: Palgrave Macmillan. https://doi.org/10.1057/9780230596047_1

Hudson, R. A. (1980). Sociolinguistics. Cambridge: Cambridge University Press.

Joseph, J. E. (1996). The Immediate Sources of the 'Sapir-Whorf Hypothesis'. Historiographia Linguistica, 23(3), 365-404. https://doi.org/10.1075/hl.23.3.07jos

Kachru, B. B. (1978). Towards structuring code-mixing: An Indian perspective. In S. N. Sridhar (Eds.), International Journal of the Sociology of Language. Aspects of Sociolinguistics in South Asia (p. 16). New York: Mouton Publishers. https://doi.org/10.1515/ijsl.1978.16.27

Kachru, B. B. (1982). The other tongue. Oxford: Pergamum.

Kachru, B. B. (1983). The Indigenization of English: The English Language in India. Delhi: Oxford University Press.

Kachru, Y. (1989). Code-mixing, Style Repertoire and Language Variation: English in Hindu Poetic Creativity. World Englishes, 8(3), 311-319. https://doi.org/10.1111/j.1467-971X.1989.tb00671.x

Krishna, S. (2012). Our Lady of Alice Bhatti. Retrieved from http://skrishnasbooks.com/2012/07/book-review-our-lady-of-alice-bhatti.html

Leech, G. N. (1996). English in Advertising. London: Longman.

Mesthrie, R., Swann, J., Deumert, A., \& Leap, W. L. (2000). Introducing Sociolinguistics. Edinburgh: Edinburgh University Press.

Muysken, P. (2000). Bilingual Speech: A typology of code-mixing. Cambridge: Cambridge University Press.

Myers-Scotton, C. (1993a). Social motivations for codeswitching: Evidence from Africa (Oxford studies in language contact.) Oxford: Clarendon.

Rahman, T. (1990). Pakistani English. Islamabad: National Institute of Pakistan Studies.

Romaine, S. (1994). Language in Society: An Introduction to Sociolinguistics. Oxford: Oxford University Press.

Spolsky, B. (1998). Sociolinguistics (Oxford introductions to language study). Oxford: Oxford University Press.

Spolsky, B. (2010). Sociolinguistics. Oxford; New York: Oxford University Press.

Van Dijk, T. (2008). Discourse and context: A sociocognitive approach. Cambridge: Cambridge University Press. https://doi.org/10.1017/CBO9780511481499

Wardhaugh, R. (1998). An introduction to Sociolinguistics (2nd ed.). Oxford: Blackwell Publishers.

Widowson, H. G. (1983). Learning Purpose and Language Use. Oxford: Oxford University Press.

Wodak, R. (2003). Multiple identities: The roles of female parliamentarians in the EU parliament. In J. Holmes \& M. Meyerhoff (Eds.), Handbook of discourse and gender (pp. 671-698). Oxford: Oxford University Press. https://doi.org/10.1002/9780470756942.ch29

\section{Appendix A}

- Doctor Sahib (p. 31).

- Dard aur, dawa aur (p. 33).

- Bhai, your blood will bring a revolution (p. 38)

- A Christian Choohra (p. 45).

- Bhatti hazir ho (p. 48).

- They are just Gaon Kachra (p. 50).

- Kala Shah Kakoo Basmati (p. 161).

- He called her nothing; just oye, or listen (p. 117).

- Over a pot of Biryani (p. 120).

- His choohra chai from choohra cup (p. 123). 
- Knee on the left, Bhai (p. 64).

- Alice takes notes in a khaki register (p. 62).

- Allopathic, homeopathic, hakims black magic type things even (p. 44).

- Christine Choohra reciting the holy Quran with the zeal of a novice mullah (p. 45).

- I am a Choohra (p. 47).

- Alice Bhatti Hazir ho (p. 48).

- I might as well have some bhang (p. 50).

- Alice takes notes in a Khaki register (p. 62).

- It's like a Cheetah (p. 48).

- All calling her Bhabhi (p. 89).

- A stove, a Charpoy (p. 92).

- Where daal and rice is a Sunday special (p. 93).

- Yasso be praised (p. 93).

- Her shalwar covers her ankles (p. 94).

- The other hand had parted his Dhoti (p. 95).

- These mushkis are very hot (p. 102).

- Welcome home, memsahib (p. 105).

- Whose name is also Yaseen (p. 126).

- Exotic plants that he has never heard of banafsha, ajwain, nazbo (p. 150).

- You go to Sunday bazaar (p. 161).

- Chanting Slogans of Ya Ali (p. 163).

- Alvi is fanning herself with dupatta (p. 164).

- A place they had started calling the kafir den (p. 172).

- Who belongs to Pakistan, Musalman, Musalman (p. 172).

- Yasoo slut and a Yahoodi spy (p. 172).

- She buys a bun Kebab (p. 178).

- Something neutral like Salamat or Saleem (p. 181).

- Aloo gosht for common priest (p. 187).

- Noor starts to educate himself (p. 197).

- Hina Alvi is an awkward driver (p. 199).

- Baskets full of guaranteed desi eggs (p. 219).

\section{Copyrights}

Copyright for this article is retained by the author, with first publication rights granted to the journal.

This is an open-access article distributed under the terms and conditions of the Creative Commons Attribution license (http://creativecommons.org/licenses/by/4.0/). 